\title{
Перший досвід хірургічного лікування гострої розшаровуючої аневризми аорти типу А через верхню серединну J-подібну міні-стернотомію
}

\author{
Вайда В. В., Жеков І. І., Кравченко В. І., Кравченко І. М., Ларіонова О. Б., \\ Лазоришинець В. В.
}

ДУ «Національний інститут серцево-судинної хірургії імені М. М. Амосова НАМН» (Київ)

\begin{abstract}
За останні роки мінімально інвазивні доступи все частіше використовуються в кардіохірургічній практиці. В Україні вже існує багато повідомлень про застосування міні-стернотомії при корекції ізольованих аортальних вад, а також у поєднанні з аневризмою висхідної аорти. Дані методики відпрацьовані та активно використовуються. Незважаючи на значний прогрес і розвиток даної галузі, описань випадків хірургічного лікування гострої розшаровуючої аневризми аорти (I тип за De Bakey) з використанням мінімально інвазивного доступу у вітчизняній літературі ми не зустрічали.

Мета роботи - представити клінічний випадок хірургічного лікування гострої розшаровуючої аневризми аорти I типу (за De Bakey) через верхню серединну J-подібну міні-стернотомію. Пацієнту 28 років із діагнозом гостра розшаровуюча аневризма аорти I типу було виконано супракоронарне протезування висхідної аорти з реконструкцією напівдуги в умовах глибокої гіпотермії та селективної антеградної церебральної перфузії через верхню серединну Ј-подібну міні-стернотомію.

Таким чином, мінімально інвазивний доступ, незважаючи на деякі технічні труднощі та враховуючи обсяг і складність оперативного втручання, дозволяє виключити недоліки, характерні для традиційної поздовжньої серединної стернотомії.
\end{abstract}

Ключові слова: міні-стернотомія, гостра розшаровуюча аневризма аорти, супракоронарне протезування висхідної аорти, реконструкція напівдуги, антеградна церебральна перфузія

Найбільш поширеною патологією аорти є аневризма. Неоперована аневризма висхідної аорти несе вкрай високий ризик розриву та раптової смерті після встановлення діагнозу. Сдиним способом зберегти життя хворого з даною патологією є хірургічне лікування.

Розшарування аорти - це розрив у стінці аорти, що змушує кров текти між шарами стінки, відділяючи їх один від одного. Розшаровуюча аневризма є невідкладним станом, який може швидко призвести до смерті, навіть за оптимального лікування.

Частота розшаровуючої аневризми - один випадок на 10000 госпіталізованих (проте значна частина хворих помирає на догоспітальному етапі); один випадок на 400 аутопсій; один хворий зі 100 померлих раптово. Загалом це 3-4\% випадків раптових смертей від серцево-судинних хвороб. Летальність від розшаровуючої аневризми становить 40-90\%. Кількість випадків розшаровуючої аневризми постійно збільшується. Без лікування рання смертність у разі розшарування становить $1 \%$ за годину в першу добу, $75 \%$ - протягом 2 тижнів і понад 90\% - протягом першого року [1].

Смертність унаслідок розриву сягає $80 \%$, а половина пацієнтів помирають ще до госпіталізації. Якщо збільшення аорти досягає в діаметрі 6 см і більше, паці$€$ єн повинен бути ургентно прооперований [4].

Мета роботи - представити клінічний випадок хірургічного лікування гострої розшаровуючої аневризми аорти I типу (за De Bakey) через верхню серединну J-подібну міні-стернотомію.

Матеріали та методи. Пацієнт В., чоловік, 28 років, поступив в Інститут з тимчасово окупованої території 23.06.2017. Пацієнту виконано клінічні та інструментальні дослідження, що включали ЕКГ, ЕхоКГ та КТ. У ході обстеження у пацієнта була діагностована гостра розшаровуюча аневризма аорти, I тип за De Bakey. За даними ЕхоКГ (23.06.2017): аортальний клапан 3 -стулковий, градієнт тиску - 9 мм рт. ст., зворотний витік - помірний, діаметр аорти - 2,3/6,3/6,5; діаметр дуги - 3,2 см; діаметр низхідної грудної аорти $-2,2$ см; діаметр черевної аорти -2,6 см; КДО - 145 мл, КСО 56 мл, УО -89 мл, ФВ - 61\%; по задній стінці ЛШ 1,5 см; по правому контуру -1 см рідини.

Дані ЕхоКГ після операції (03.07.2017): зворотний витік на аортальному клапані - мінімальний; діаметр висхідної аорти - 3,9 см; КДО - 135 мл, КСО - 57 мл, УО - 78 мл, ФВ - 60\%; рідина в порожнині перикарда - відсутня. 
Зі слів пацієнта, він відчув різкий біль за грудиною і виражену слабість 21.06.2017. 3 огляду на загрозливий для життя стан пацієнта було прийнято рішення про екстрену операцію за життєвими показаннями.

При положенні хворого на спині розріз шкіри ( 8 см) проводився поздовжньо від яремної вирізки до четвертого міжреберного проміжку. Грудина розсікалася поздовжньо до цього ж рівня праворуч у міжребер'ї. Після обробки країв грудини гемостатичною губкою встановлювався ретрактор. Одночасно виконувався доступ до лівої стегнової артерії для постановки артеріальної лінії. Перикард був розсічений поздовжньо, із Т-подібним розсіченням у нижньому краї операційної рани. Краї перикарда фіксувалися лігатурами для зручної та кращої візуалізації операційного поля. Для забезпечення штучного кровообігу після введення гепарину канюлювали ліву стегнову артерію за прийнятою в Інституті методикою. Венозна (двопросвітна) канюля встановлювалась у вушко правого передсердя. Дренування лівого шлуночка виконували через гирло правої верхньої легеневої вени. Кардіоплегічна канюля була встановлена в коронарний синус для забезпечення доставки кардіоплегічного розчину за комбінованою методикою. Після затиснення аорти та зупинки серцевої діяльності (комбінована - антеретроградна кардіоплегія, кустодіол - 10-20 мл/кг) виконували поздовжню аортотомію та проводилася ревізія аортального клапана та анатомії розриву. Розрив інтими був циркулярним, на один сантиметр вище вічка правої коронарної артерії. В даному випадку клапан виявився компетентним, синотубулярне з'єднання було не розширеним. Були проведені три шви на комісуральних з'єднаннях з подальшою ресуспензією аортального клапана. Для повного відсічення аорти необхідно було відділити висхідну аорту від стінки стовбура легеневої артерії. Одночасно виконувалося загальне охолодження організму до $24 € \mathrm{C}$ для ревізії аорти на предмет поширення розриву на дугу аорти з можливим ураженням брахіоцефальних судин. Було знято затискач з аорти. Для адекватного захисту головного мозку виконувалася селективна (tr. brachiocephalicus та a.carrotis comunis) антеградна церебральна перфузія. Отже, в умовах глибокої гіпотермії $(24 € C)$ та селективної антеградної церебральної перфузії (33 хв.) було виконано супракоронарне протезування висхідної аорти з реконструкцією напівдуги. Було використано судинний протез Vascutek $(\mathrm{d}=28 \mathrm{~mm}, \mathrm{l}=80 \mathrm{~mm})$. Судинний протез не огортався залишками аневризматичного мішка, було виконано «відкритий» анастомоз. Судинний протез не огортався залишками аневризматичного мішка. Дистальний і проксимальний анастомоз укріплені тефлоновими смужками та прошивалися дворядними швами (спочатку матрацний шов, потім вузловий безперервний) проленом №3. Операція закінчена за звичайною методикою.

Результати та обговорення. Пацієнт добре переніс операцію. Тривалість втручання становила 360 хв. Тривалість штучного кровообігу склала 141 хв. Час перетиснення аорти склав загалом 86 хв. Інтраопераційна крововтрата дорівнювала 300 мл. Крововтрата в першу післяопераційну добу склала 175 мл. Механічна вентиляція тривала 6,5 годин після втручання. Пацієнт був переведений з BPIT на 36-ту годину після операції. Відзначено більш швидку реабілітацію хворого, менш виражені скарги на больові відчуття, а отже, й меншу потребу в ін'єкціях анальгетиків.

Висновки. Таким чином, описана методика, незважаючи на деякі технічні труднощі та враховуючи об'єм і складність оперативного втручання, дозволяє виключити недоліки, характерні для традиційної поздовжньої серединної стернотомії. Метод мінімізує травму, забезпечує гарний косметичний ефект і може бути використаний у клінічній практиці. Пропонована методика може застосовуватися не тільки при корекції ізольованих аортальних вад, а й навіть при таких життєво загрозливих станах, як гостра розшаровуюча аневризма аорти. Даний метод дозволяє покращити результативність, зменшити кількість ускладнень, покращити якість життя та реабілітацію в даної когорти пацієнтів у післяопераційному періоді.

\section{Література}

1. Ситар Л. Л. Аневризми грудної аорти. - 2011. C. 83-89.

2. Минимально инвазивная хирургия сердца / под ред. Л. А. Бокерия. - М., 2008. - 92 с.

3. Бокерия Л. А., Скопин И. И., Нарсия Б. Е. Результаты протезирования аортального клапана из мини-доступов // Бюллетень НЦССХ им. А. Н. Бакулева РАМН. Материалы X Всероссийского съезда сердечнососудистых хирургов. - М., 2014. - № 11. - Том 5. C. 187.

4. Antegrade delivery of stent grafts to treat complex thoracic aortic disease / Roselli E. E., Soltesz E. G., Mastracci T. et al. // Ann Thorac Surg. - 2013. - Vol. 90. - P. 539-546. 10. 1016/j.athoracsur.2013.04.040. 


\title{
The first experience of surgical treatment of acute aortic dissection (type A) through the upper middle J-shaped ministernotomy
}

\author{
Vayda V. V., Zhekov I. I., Kravchenko V. I., Kravchenko I. M., Larionova O. B., Lazoryshynets V. V.
}

National M. M. Amosov Institute of Cardiovascular Surgery National Academy of Medical Sciences of Ukraine (Kyiv)

In recent years, minimally invasive access has increasingly been implicated in cardiac surgery. Already there are many reports in Ukraine about the use of ministernotomy for correction of isolated aortic defects, as well as in conjunction with an ascending aortic aneurysm. These techniques are worked out and actively used. Despite the significant progress and development in this field, cases of surgical treatment of acute aortic dissection (type I for De Bakey) in Ukrainian literature we did not meet.

To present a clinical case of surgical treatment of acute aortic dissection type A through the upper middle J-shaped ministernotomy. A patient, 28 years old, with a diagnosis of acute aortic aneurysm dissection type A, who undergone supracoronary replacement of the ascending aorta with hemiarch reconstruction under conditions of deep hypothermia and selective antegrade cerebral perfusion through the upper middle J-shaped ministernotomy.

Thus, minimally invasive access, despite some technical difficulties, and taking into account the volume and complexity of surgical intervention, eliminates the disadvantages that are characteristic of the traditional longitudinal median sternotomy.

Key words: ministernotomy, acute aortic dissection, supracoronary replacement of the ascending aorta, hemiarch reconstruction, antegrade cerebral perfusion.

\section{Первый опыт хирургического лечения острой расслаивающей аневризмы аорты типа А через верхнюю срединную Ј-образную мини-стернотомию}

\author{
Вайда В. В., Жеков И. И., Кравченко В. И., Кравченко И. Н., Ларионова О. Б., Лазоришинец В. В. \\ ГУ «Национальный институт сердечно-сосудистой хирургии имени Амосова НАМН» (Киев)
}

За последние годы минимально инвазивные доступы все чаще используются в кардиохирургической практике. В Украине уже существует много сообщений о применении мини-стернотомии при коррекции изолированных аортальных пороков, а также в сочетании с аневризмой восходящей аорты. Данные методики отработаны и активно используются. Несмотря на значительный прогресс и развитие данной области, описания случаев хирургического лечения острой расслаивающей аневризмы аорты (I тип по De Bakey) с использованием минимально инвазивного доступа в отечественной литературе мы не встречали.

Цель работы - представить клинический случай хирургического лечения острой расслаивающей аневризмы аорты I типа (по De Bakey) через верхнюю срединную Ј-образную мини-стернотомию. Пациенту 28 лет с диагнозом острая расслаивающая аневризма аорты I типа было выполнено супракоронарное протезирование восходящей аорты с реконструкцией полудуги в условиях глубокой гипотермии и селективной антеградной церебральной перфузии через верхнюю срединную Ј-образную мини-стернотомию.

Таким образом, минимально инвазивный доступ, несмотря на некоторые технические трудности, а также объем и сложность оперативного вмешательства, позволяет исключить недостатки, характерные для традиционной продольной срединной стернотомии.

Ключевые слова: мини-стернотомия, острая расслаивающая аневризма аорты, супракоронарное протезирование восходящей аорты, реконструкция полудуги, антеградная церебральная перфузия. 